\title{
5-HT Modulation of Dopamine Release in Basal Ganglia in Psilocybin-Induced Psychosis in Man-A PET Study with $\left[{ }^{11} \mathrm{C}\right]$ raclopride
}

Franz X. Vollenweider, M.D., Peter Vontobel, Ph.D., Daniel Hell, M.D., and Klaus L. Leenders, M.D.

The modulating effects of serotonin on dopamine neurotransmission are not well understood, particularly in acute psychotic states. Positron emission tomography was used to examine the effect of psilocybin on the in vivo binding of $\left[{ }^{11} \mathrm{C}\right]$ raclopride to $D_{2}$-dopamine receptors in the striatum in healthy volunteers after placebo and a psychotomimetic dose of psilocybin $(n=7)$. Psilocybin is a potent indoleamine hallucinogen and a mixed $5-\mathrm{HT}_{2 \mathrm{~A}}$ and $5-H T_{1 A}$ receptor agonist. Psilocybin administration $(0.25$ $\mathrm{mg} / \mathrm{kg}$ p.o.) produced changes in mood, disturbances in thinking, illusions, elementary and complex visual hallucinations and impaired ego-functioning. Psilocybin significantly decreased $\left[{ }^{11} \mathrm{C}\right]$ raclopride receptor binding potential (BP) bilaterally in the caudate nucleus (19\%) and putamen (20\%) consistent with an increase in endogenous dopamine. Changes in $\left[{ }^{11} \mathrm{C}\right]$ raclopride $B P$ in the ventral striatum correlated with depersonalization associated with euphoria. Together with previous reports of 5-HT receptor involvement in striatal dopamine release, it is concluded that stimulation of both $5-\mathrm{HT}_{2 A}$ and $5-\mathrm{HT}_{1 A}$ receptors may be important for the modulation of striatal dopamine release in acute psychoses. The present results indirectly support the hypothesis of a serotonin-dopamine dysbalance in schizophrenia and suggest that psilocybin is a valuable tool in the analysis of serotonin-dopamine interactions in acute psychotic states. [Neuropsychopharmacology 20:424433, 1999] (C) 1999 American College of Neuropsychopharmacology. Published by Elsevier Science Inc.
KEY WORDS: Psilocybin; Indoleamine hallucinogen; Model psychosis; Serotonin; $5-\mathrm{HT}_{2 A}$ receptor; $5-\mathrm{HT}_{1 A}$ receptor; Dopamine; $\mathrm{D}_{2}$ receptor; Striatum; Psychopathology; Human; Schizophrenia; Positron Emission Tomography (PET); $\left[{ }^{11}\right.$ Clraclopride

Psilocybin, a potent indoleamine hallucinogen and 5-HT receptor stimulating agent, has been reported to

From the Research Department (FXV, DH), Psychiatric University Hospital Zürich, Zürich, Switzerland; the PET Department (FXV, PV, KLL), Paul Scherrer Institute, Villigen, Switzerland; and the Neurology Department, University Hospital Zürich (KLL), Zürich, Switzerland.

Address correspondence to: Dr. Franz X. Vollenweider, Psychiatric University Hospital Zürich, Research Department, P.O. Box 68, CH-8029 Zürich, Switzerland.

Received August 25, 1997; accepted September 17, 1998. produce a psychosis-like syndrome in man resembling the first manifestation of schizophrenia in certain respects [for review see (Fischman 1983; Gouzoulis-Mayfrank et al. 1998)]. Particularly, ego-disorders (Rümmele and Gnirss 1961; Vollenweider et al. 1997), affective changes (Rümmele and Gnirss 1961), loosened associations (Spitzer et al. 1996) and perceptual alterations commonly seen in psilocybin-induced psychosis are also observed in incipient acute schizophrenic stages (Bowers and Freedman 1966; Heimann, 1986; Gouzoulis et al. 1994). In support of these suggested clinical similarities, we recently found that psilocybin produced a marked prefrontal and anterior cingulate activation in normal subjects comparable to the hyperfrontal pattern observed in some (Cleghorn et al. 1989; Ebmeier et al. 1993, 1995; Catafau et al. 1994; Parellada 
et al. 1994; Ebmeier et al. 1995; Sabri et al. 1997) but not all (Andreasen et al. 1992; Buchsbaum et al. 1992; Liddle et al. 1992; Siegel et al. 1993) acute schizophrenic patients. A number of functional animal studies have suggested that indoleamine (psilocybin, LSD) and phenylethylamine (DOI, mescaline) hallucinogens produce their psychotomimetic effects primarily through excessive stimulation of 5- $\mathrm{HT}$, and $5-\mathrm{HT}_{2 \mathrm{~A}}$ receptors in particular (McKenna et al. 1989; Pierce and Peroutka 1989; Aghajanian 1994; Sipes and Geyer 1994; Padich et al. 1996). This assumption was corroborated in a recent human study demonstrating that the psychotomimetic effects of psilocybin can be blocked dose-dependently by pretreatment with the preferential $5-\mathrm{HT}_{2 \mathrm{~A}}$ receptor antagonist ketanserin (Vollenweider et al. 1998). However, pretreatment with the $\mathrm{D}_{2}$-antagonist haloperidol also reduces some of the positive symptoms of psilocybin psychosis. This raises the possibility that symptoms of psilocybin are secondary responses to increased dopaminergic transmission (Vollenweider et al. 1998). Hence, a contribution of the dopamine systems to the effects of psilocybin, presumably through a serotonindopamine interaction, cannot be ruled out.

Functional interactions between central serotonin (5-HT) and dopamine (DA) systems have been well documented. Electrophysiological, biochemical, and behavioral evidence suggests that the ascending serotonergic pathways from the medial and dorsal raphe modulate or control the function of the mesolimbic and mesostriatal dopamine systems (Joyce 1993; Zazpe et al. 1994; Kapur and Remington 1996). The modulating effect of serotonin on striatal dopamine release is, however, controversial. For example, there is evidence that serotonin may inhibit (de Belleroche and Bradford 1980; Ennis et al. 1981; Westfall and Tittermary 1982; Blandina et al. 1988) as well as stimulate DA release in the striatum (Benloucif et al. 1993; West and Galloway 1996; De Deurwaerdere et al. 1997). Similarly, local application of 5-HT or 5-HT agonists have been shown to reduce (de Belleroche and Gardiner 1982) and facilitate dopamine efflux in the nucleus accumbens (Guan and McBride 1989; Parson and Justice 1993). In respect to the $5-\mathrm{HT}_{2}$ receptor agonist properties of psilocybin, it is of particular note that 3,4-methylenedioxymethamphetamine (MDMA), a potent 5-HT releasing agent, has been shown to increase impulse-mediated striatal dopamine release through $5-\mathrm{HT}_{2}$ receptor activation (Schmidt et al. 1992; Palfreyman et al. 1993; Schmidt et al. 1994; Yamamoto et al. 1995; Gudelsky and Nash 1996). Thus, $5-\mathrm{HT}_{2 \mathrm{~A}}$ receptors located on dopaminergic and/or GABAergic neurons within the striatum and nucleus accumbens might provide an anatomical substrate for a serotonin-mediated psilocybin-induced dopamine release (Palacios et al. 1991).

The serotonin agonist psilocybin binds with high affinity at $5-\mathrm{HT}_{2 \mathrm{~A}}(\mathrm{Ki}=6 \mathrm{nM})$ and to a lesser extent at
$5-\mathrm{HT}_{1 \mathrm{~A}}(\mathrm{Ki}=190 \mathrm{nM})($ McKenna et al. 1990) receptors. More importantly, psilocybin and its centrally active metabolite psilocin have - in contrast to the classic indoleamine hallucinogen LSD - no affinity for dopamine $\mathrm{D}_{2}$ receptors $(\mathrm{Ki}=17,000 \mathrm{nM})$ (Creese et al. 1975). The present pilot study was designed to investigate the impact of 5-HT receptor stimulation upon the dopamine systems by exploring the effect of a hallucinatory dose of psilocybin on striatal DA release in healthy volunteers. Positron emission tomography and the selective radioligand $\left[{ }^{11} \mathrm{C}\right]$ raclopride was used to examine the degree of striatal $\mathrm{D}_{2}$-dopamine receptor occupancy in the brain of healthy volunteers before and after single oral dose of psilocybin. This technique has been shown to be suitable to asses the effects of dopaminergic drugs on endogenous dopamine release (Dewey et al. 1993; Dewey et al. 1995), while a high test-retest reliability of PET with $\left[{ }^{11} \mathrm{C}\right]$ raclopride has been reported in healthy subjects (Nordström et al. 1992; Volkow et al. 1993). Based on our recent finding, that the $\mathrm{D}_{2}$ antagonist haloperidol partly reduces psilocybin-induced psychotic symptoms, we hypothesized that psilocybin might increase striatal dopamine release.

\section{METHODS}

\section{Experimental Design}

The study was approved by the Ethics Committee of the Psychiatric University Hospital Zürich and the use of psychoactive drugs by the Swiss Federal Health Office, Department of Pharmacology and Narcotics, Berne.

Subjects. Seven male healthy volunteers (age, $27 \pm$ 2.3 years) were recruited from university and hospital staff. Written consent was obtained. The subjects were screened by psychiatric interview to assure that the subjects had neither personal nor family histories of major psychiatric disorders in first-degree relatives. Subjects with a history of illicit drug abuse were excluded from the study. The "openness" and "neuroticism" scales of the Freiburg Personality Inventory (FPI) (Fahrenberg et al. 1984) were also used as exclusion criteria. Subjects were healthy according to physical examination, electrocardiogram, blood, and urine analysis.

Design. All subjects participated in two $\left[{ }^{11} \mathrm{C}\right]$ raclopride PET investigations, during which psilocybin or placebo was orally administered in a single blind fashion. PET scans were performed at monthly intervals and psilocybin and placebo were given in a randomized order across subjects. Based on previous psilocybin studies conducted in normals (Hasler et al. 1997; Vollenweider et al. 1997), psilocybin was dosed high enough $(0.25 \mathrm{mg} / \mathrm{kg}$ p.o.) to induce illusions, hallucinations, changes of affect, and loosening of ego boundaries over a period of 120-180 minutes. After fasting 
subjects ingested capsules (8.00 AM) containing psilocybin 80 minutes before $\left[{ }^{11} \mathrm{C}\right]$ raclopride injection so that the PET measurement would coincide with the peak effect of the drug (Hasler et al. 1997). Psychopathological ratings were performed immediately after PET scanning (140 minutes after placebo or psilocybin intake).

Psychometric Scales. The "Altered State of Consciousness" (APZ-OAV) rating scale, a visual-analog scale and slightly modified version of the original APZ rating scale (66 instead of 72 items), was used to assess drug effects under placebo and drug conditions (Dittrich 1996). The APZ-OAV yields 3 dimensions (factors) comprised of several item clusters (Dittrich 1994). The first subscale, OSE ("oceanic boundlessness"), measures derealisation and depersonalisation associated with a positive basic mood ranging from enhanced well-being to grandiosity. The corresponding item clusters include "derealisation," "depersonalisation," "altered sense of time," "positive basic mood," and "mania-like experience." The second subscale, VUS ("visionary restructuralization"), includes illusions, (pseudo-) hallucinations, synaesthesia, and altered experience of meaning. Item clusters are labeled "illusions," "hallucinations," "synaesthesias," "changed meaning of percepts," "facilitated recollection of memories," and "facilitated imagination." The third subscale, AIA ("anxious ego-dissolution"), measures thought disorder, delusions and loss of control over body and thought associated with arousal and anxiety. The item clusters are "frightening derealisation," "thought disorder," "delusion," "loss of thought control," and "loss of body control."

Substance. Psilocybin (o-Phosphoryl-4-hydroxy-N, Ndimethyl-tryptamine) was obtained through the Swiss Federal Health Office (BAG), Department of Pharmacology and Narcotics, Berne.

\section{PET Procedure}

The $\left[{ }^{11} \mathrm{C}\right]$ raclopride PET scans were performed on a CTI 933/04-16 scanner. The spatial resolution of this scanner for 7 simultaneously acquired slices is after reconstruction $8 \mathrm{~mm}$ transaxially (full width half maximum).

Subjects were positioned in the scanner using an individually moulded head support. The head was aligned with the orbito-meatal line parallel to the detector ring with the help of laser beams. Just before tracer administration a 10-min transmission scan was collected using an external ring source of ${ }^{68} \mathrm{Ga} /{ }^{68} \mathrm{Ge}$ to correct for attenuation of $\gamma$-radiation by the brain and skull. Subjects received intravenous infusions of $\left[{ }^{11} \mathrm{C}\right]$ raclopride (in $10 \mathrm{ml}$ saline; infused over $3 \mathrm{~min}$ ) at the start of the scan. The injected dose was $238 \pm 83$ $\mathrm{MBq}$ (specific activity $10 \pm 7 \mathrm{TBq} / \mathrm{mmol}$ ). At the start of the infusion a standardized sequence of scans was recorded for a 60-min study period.

\section{Image Analysis and Modelling of Data}

Regions of interest (ROIs) were placed on the images with the highest tracer activity in the striatal regions and cerebellum using a standard template arrangement. A circular ROI $\left(62,5 \mathrm{~mm}^{2}\right)$ was placed over the caudate nucleus and ventral striatum (nucleus accumbens) of each hemisphere. On the putamen of each hemisphere an elliptical ROI $\left(250 \mathrm{~mm}^{2}\right)$ was placed. A further elliptical ROI $\left(780 \mathrm{~mm}^{2}\right)$ was placed over each cerebellar hemisphere. Regional time-activity curves were plotted for each subject and the data were analyzed using a reference tissue model with a cerebellar input function (Lammertsma and Hume 1996). This method measures the binding potential (BP), a measure of the ratio of receptor density and equilibrium dissociation constant $\left(\mathrm{B}_{\max } / \mathrm{K}_{\mathrm{d}}\right)$. Assuming that the $\mathrm{K}_{\mathrm{d}}$ is unaffected by psilocybin, the BP provides a measure of the number of available $D_{2}$-dopamine receptors in the caudate nucleus and putamen. Changes in raclopride binding potentials $\left(\mathrm{B}_{\max } / \mathrm{K}_{\mathrm{d}}\right)$ from placebo to psilocybin experiments were assessed as percent from placebo and calculated as follows: change $(\%)=\left(\mathrm{BP}_{\text {psilocybin }}-\mathrm{BP}_{\text {placebo }}\right) /$ $\mathrm{BP}_{\text {placebo }} \times 100$. To look for left-right asymmetries of raclopride binding during placebo and psilocybin experiments, asymmetry indices were calculated for all ROI's accordingly: $\mathrm{ASI}_{\mathrm{ROI}}=\left(\mathrm{BP}_{\text {left }}-\mathrm{BP}_{\text {right }}\right) /\left(\mathrm{BP}_{\text {left }}+\right.$ $\left.\mathrm{BP}_{\text {right }}\right) \times 200$.

\section{Statistical Analysis}

In this study, each subject served as his or her own control to minimize the effect of interindividual variation in psychopathology scores and PET measures. To examine differences in psychopathology scores or raclopride binding potentials between placebo and psilocybin, repeated measures ANOVAs with session as repeated factor were used. The Spearman correlation coefficient was used to evaluate correlations between changes in raclopride binding potentials and psycho(patho)logical alterations. The criterion for significance was set at $\mathrm{p}<.05$.

\section{RESULTS}

Psilocybin administration $(0.25 \mathrm{mg} / \mathrm{kg}$, p.o.) produced a psychotic syndrome that included disturbances of emotion and sensory perception, difficulties in thinking and in reality appraisal, as well as impairment of egofunctioning manifested as a loss of ego-boundaries. The psychotic symptoms appeared 20 to 30 minutes after oral ingestion of psilocybin and peaked after another 30 to 40 minutes, lasting for 1 to 2 hours. Subsequently symptoms slowly declined and completely subsided 5 to 6 hours after their initial appearance. During the 
peak period perceptual alterations included auditory and visual disturbances ranging from illusions to complex scenery hallucinations (VUS; Table 1). Subjects reported difficulties in concentrating and attention, thinking was accelerated or slowed down, whereas derealisation phenomena sometimes influenced the content of thought. As seen in Table 1, psilocybin also produced derealisation phenomena and loosening of egoboundaries (OSE, AIA). In 4 of the 7 subjects, these symptoms were associated predominately with heightened mood, euphoria or a feeling of grandiosity (relatively high OSE and moderate AIA scores), while 3 of the subjects reacted with anxiety as indicated by relatively high AIA scores.

As seen in Figure 1, administration of psilocybin decreased $\left[{ }^{11} \mathrm{C}\right]$ raclopride receptor binding potential (BP) bilaterally in the striatum as compared to placebo condition. This finding suggests an increase in $\mathrm{D}_{2}$-dopamine receptor occupancy by endogenous dopamine. Peak uptake of $\left[{ }^{11} \mathrm{C}\right]$ raclopride occurred 17 minutes after radiotracer injection and cleared to $37 \%$ of the peak value by 60 minutes post injection. The initial brain extraction of $\left[{ }^{11} \mathrm{C}\right]$ raclopride was not affected by psilocybin pretreatment. Analysis of asymmetry indices revealed no significant left-right asymmetries of $\left[{ }^{11} \mathrm{C}\right]$ raclopride BP in the caudate nucleus, putamen or ventral striatum, neither under placebo nor psilocybin condition. At 130 minutes after psilocybin ingestion, the reduction of tracer binding in the striatum averaged $19 \%$. Significant mean $( \pm \mathrm{SE})$ decreases of $\left[{ }^{11} \mathrm{C}\right]$ raclopride BP were seen in the caudate nucleus (left: $19.9 \pm$ $5.5 \%, p<.01 /$ right: $18.6 \pm 5.4 \%, p<.05)$ and putamen $(21.0 \pm 6.8 \%, p<.05 / 18.5 \pm 4.8 \%, p<.01)$, while the decrease in the ventral striatum just missed statistical significance in the right side (left: $12.9 \pm 8.0 \%, p=.12$ / right: $18.8 \pm 9.3 \%, p=.056$ ). As seen in Figure 2, the decrease in $\left[{ }^{11} \mathrm{C}\right]$ raclopride $\mathrm{BP}$ in the ventral striatum cor-

Table 1. Increases in APZ-OAV Scores OSE (oceanic boundlessness), VUS (visionary restructuralization), AIA (anxious ego-dissolution), and OSE-DEP (OSE depersonalisation) Subscore from Placebo to Psilocybin in Healthy Volunteers

\begin{tabular}{lcccc}
\hline Subjects & OSE & OSE-DEP & VUS & AIA \\
\hline 1 & 1925 & 328 & 1257 & 325 \\
2 & 2152 & 290 & 1465 & 523 \\
3 & 859 & 230 & 1145 & 309 \\
4 & 2084 & 326 & 904 & 87 \\
5 & 1614 & 55 & 983 & 670 \\
6 & 810 & 44 & 634 & 86 \\
7 & 1860 & 480 & 1444 & 1111 \\
Mean \pm SE & $1614 \pm 211^{a}$ & $250 \pm 59^{b}$ & $1118 \pm 113^{a}$ & $444 \pm 137^{c}$
\end{tabular}

Significantly different from placebo:

${ }^{a}$ for $p<.001$;

${ }^{b}$ for $p<.01$;

${ }^{c}$ for $p<.05$. related with the increase in "depersonalisation" subscores of the OSE dimension (left and right: $\mathrm{R}_{\mathrm{Sp}}=.96$, $p<.0005)$. No other correlations between changes in receptor BP and psychometric scores were found.

\section{DISCUSSION}

As previously reported, psilocybin given to healthy volunteers produced changes in mood, disturbances in thinking, illusions, elementary and complex visual hallucinations, as well as impairment of ego-functioning (Heimann 1986; Spitzer et al. 1996; Vollenweider et al. 1997). Most prominent among these symptoms were derealisation and depersonalisation associated with heightened mood or euphoria (OSE). There was also a marked increase in perceptual alterations (VUS), with elementary hallucinations being more pronounced than complex hallucinations and synaesthesias. However, we observed only a moderate increase in anxious ego dissolution (AIA). These findings are reminiscent of reports that the earliest affective changes in schizophrenic patients are often pleasurable (Bowers and Freedman 1966; Chapman 1966; Gouzoulis et al. 1994), and of the clinical observation that visual hallucinations occur significantly more often in acute than in chronic schizophrenic patients (McCabe et al. 1972; Freedman and Chapman 1973; Gouzoulis et al. 1994). Loosening of ego-boundaries and impaired thought control as measured by OSE and AIA, however, are not only common features of psilocybin-induced psychosis (Rümmele and Gnirss 1961; Bowers and Freedman 1966; Heimann, 1986; Vollenweider et al. 1997) and early schizophrenic stages, but also occur in chronic schizophrenics in acute episodes (Fischman 1983). Indeed, a recent study demonstrated that schizophrenic patients during both first episodes and relapse had similar OSE and AIA scores as seen in this study in psilocybin subjects (GouzoulisMayfrank et al. 1998). However, unlike schizophrenics, most of psilocybin subjects recognized derealisation and depersonalisation as abnormal experiences and attributed them to the drug. A further difference between psilocybin-induced psychosis and schizophrenia is the rare occurrence of auditory hallucinations in psilocybin psychosis. Nevertheless, the present data in combination with previous findings suggest that psilocybin can produce a psychotic syndrome that resembles in certain respects acute schizophrenic decompensation.

The present data demonstrate that psilocybin decreased $\left[{ }^{11} \mathrm{C}\right]$ raclopride binding in the caudate nucleus and putamen in human subjects, reflecting an increase in striatal dopamine concentration. This raises the possibility that some of the observed psychosis-like symptoms were manifestations of increased striatal dopamine activity. In support of this assumption, we observed a strong correlation between the OSE depersonalisation 
A)

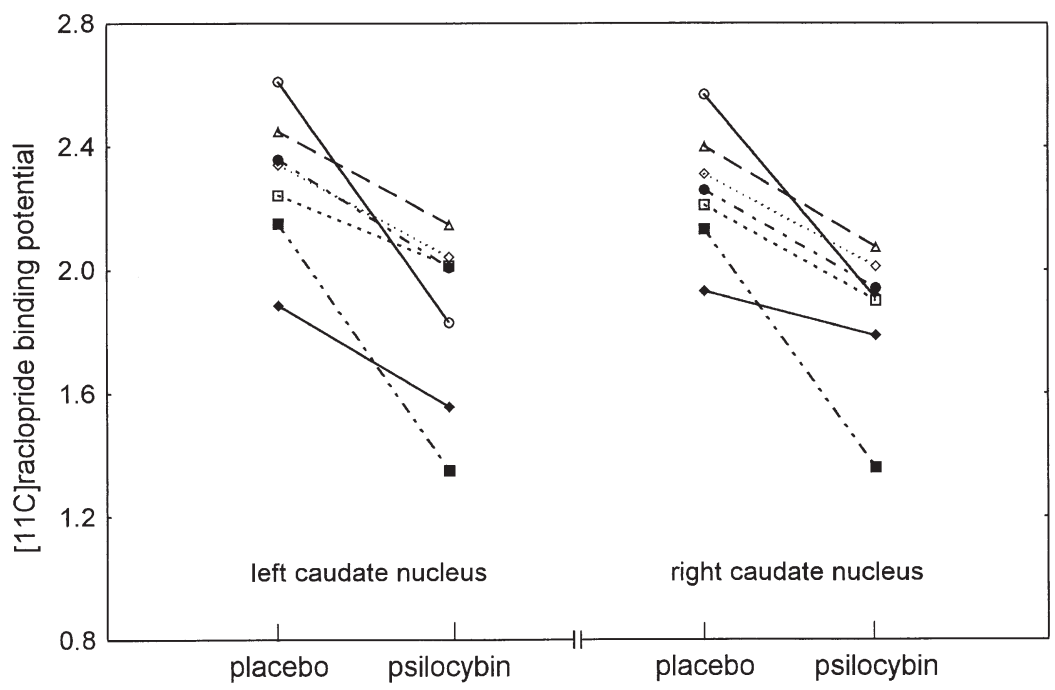

B)

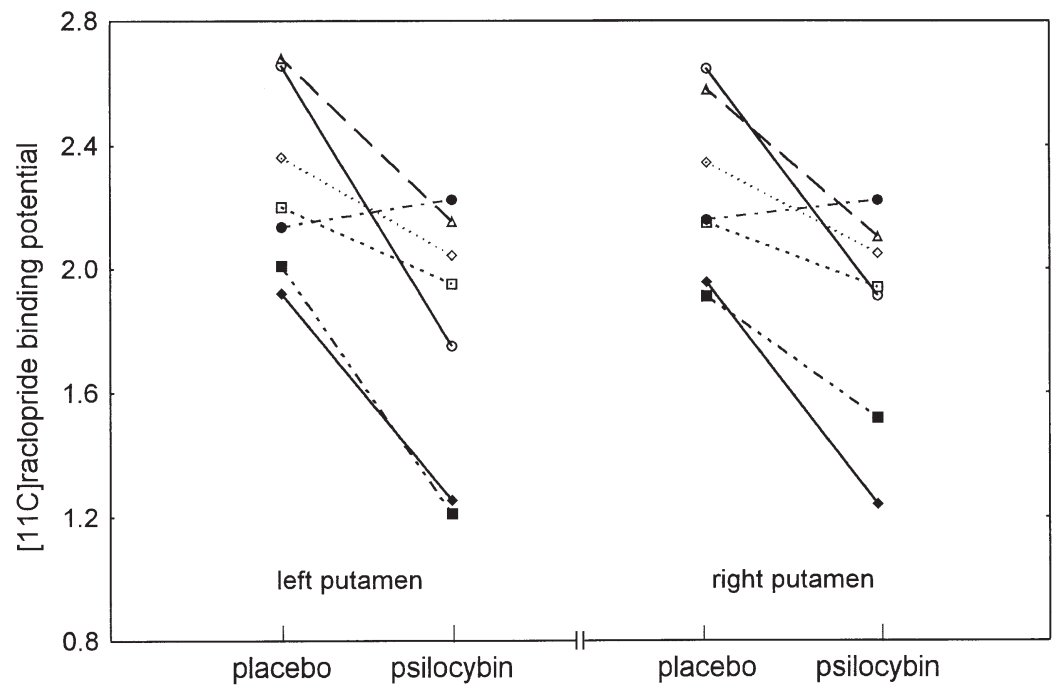

C)

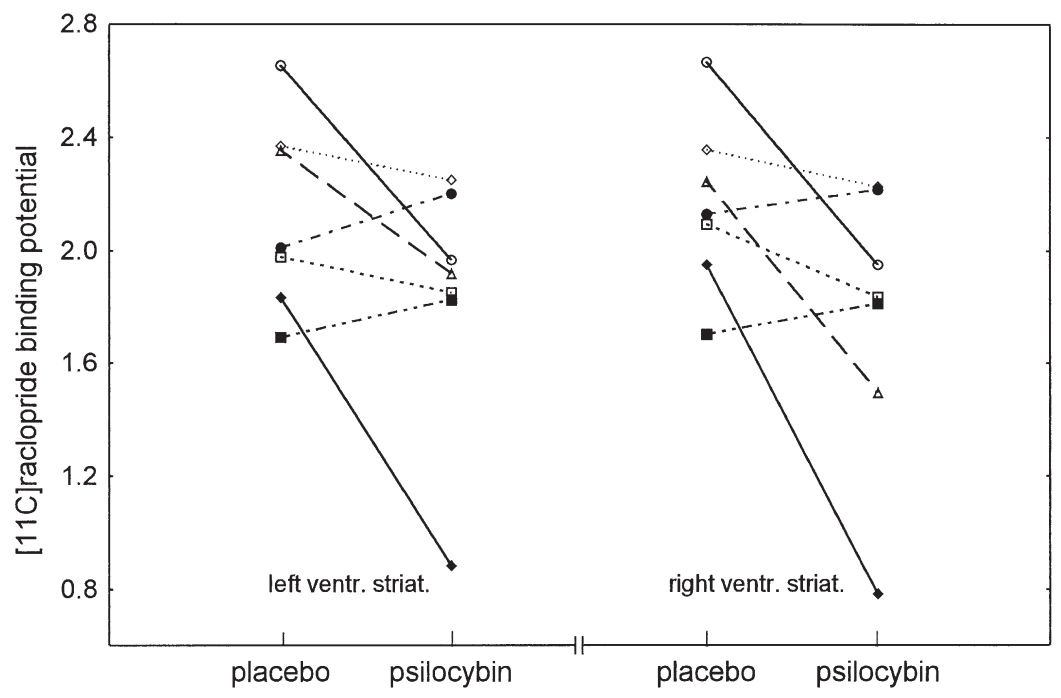

Figure 1. Changes in $\left[{ }^{11} \mathrm{C}\right]$ raclopride binding potential $\left(\mathrm{BP}=\mathrm{B}_{\max } / \mathrm{K}_{\mathrm{d}}\right)$ in (A) caudate nucleus, (B) putamen, and (C) ventral striatum during the peak phase of psilocybininduced psychosis. Psilocybin significantly decreased $\left[{ }^{11} \mathrm{C}\right]$ raclopride $\mathrm{BP}$ in the caudate nucleus and putamen consistent with an increase in dopamine activity. 


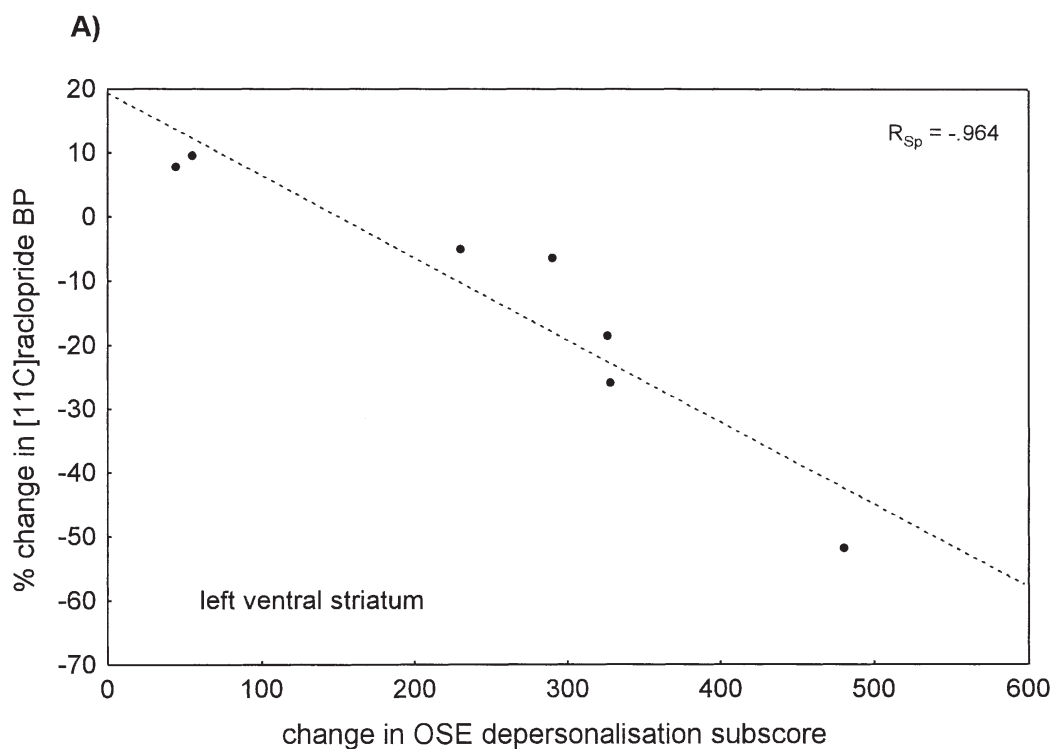

B)

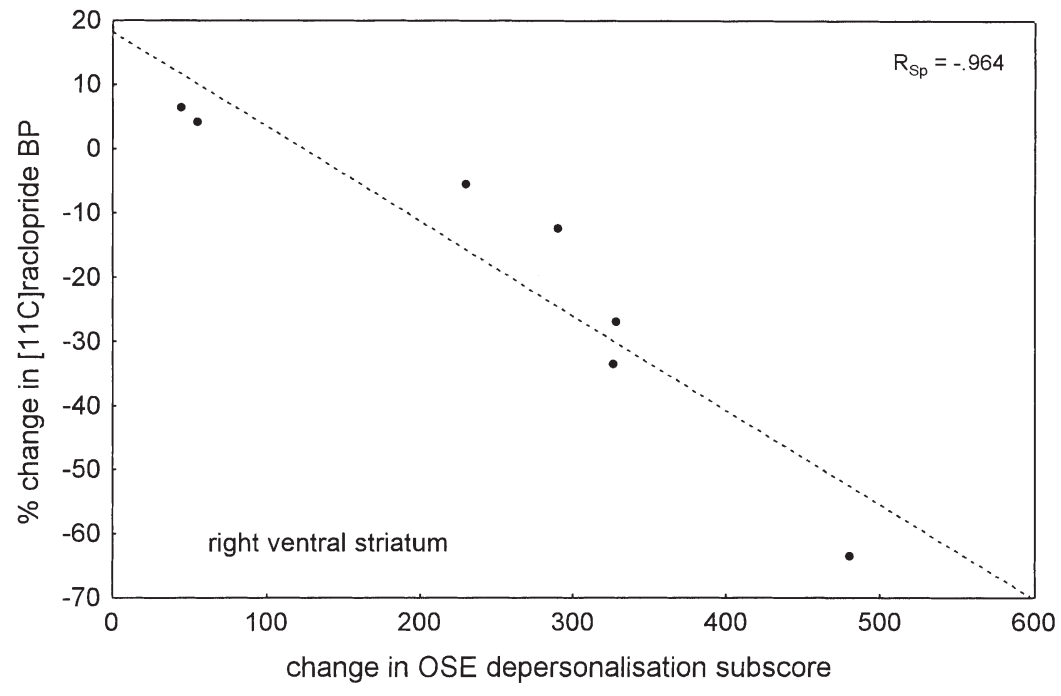

Figure 2. Correlation between psilocybininduced increases in depersonalisation subscores of the OSE scale and decrease in $\left[{ }^{11} \mathrm{C}\right]$ raclopride binding potential (\% from placebo): (A) for the left and (B) for the right ventral striatum. subscore and the change in $\mathrm{D}_{2}$ receptor $\mathrm{BP}$ in the ventral striatum. Furthermore, consistent with this possibility, we recently found that the $\mathrm{D}_{2}$ antagonist haloperidol attenuated psilocybin-induced depersonalisation, derealisation and euphoria (Vollenweider et al. 1998). Interestingly, we recently also found a correlation of increased ventral striatal dopamine with OSE depersonalisation subscores in ketamine-induced psychosis (Vollenweider FX, Vontobel P, Øye I, Hell D, Leenders KL (1998a): Effects of S-ketamine on striatal dopamine release: a [11C]raclopride PET study of a model psychosis in humans. (submitted to J Psych Res)). A similar correlation between schizophrenia-like symptoms and changes in raclopride specific binding in the striatum has been reported in a ketamine study with healthy normals (Breier et al. 1998). Finally, in a SPECT study, amphetamine-induced decrease in striatal [123I]IBZM
BP was associated with a worsening of positive psychotic symptoms in schizophrenic patients (Laruelle et al. 1996). Taken together, these findings suggest that elevation of dopamine release in the striatum, particularly in the ventral striatum, contributes to the formation of psychotic symptoms, especially those associated with affective changes ranging from enhanced mood to euphoria and grandiosity. However, it is also possible that these affective changes are the main manifestations of striatal dopamine release. Such a view is supported by a SPECT study reporting a correlation between amphetamine-induced decrease in striatal $\mathrm{D}_{2}$ availability and euphoria and alertness in healthy normals (Laruelle et al. 1995). In this latter study psychotic symptoms were not observed despite changes in striatal dopamine indices of similar magnitude as seen in the present study. Thus, it may be argued that, in psilocybin psy- 
chosis, specifically those aspects of psychotic symptoms related to euphoria and alertness may be mediated by striatal dopamine release, but that striatal dopamine release alone cannot account for the occurrence of psilocybin-induced psychotic symptoms. In this respect, it is of note that haloperidol had virtually no effect on psilocybin-induced hallucinations (VUS) and even increased anxious ego-dissolution (AIA) in psilocybin subjects, while ketanserin, a preferential $5-\mathrm{HT}_{2 \mathrm{~A}}$ receptor antagonist, dose-dependently prevented psilocybin psychosis (Vollenweider et al. 1998). Thus, it appears that most of the psilocybin-induced psychotic symptoms may be mediated preferentially by serotonergic rather than mesostriatal dopaminergic systems. Finally, the present data do not allow to rule out a contribution of extrastriatal dopamine systems in psilocybin-induced psychosis.

There are a number of caveats to these speculations. First, data concerning striatal dopamine levels cannot be directly compared between different studies. For example, the PET ligands and mathematical models for determining shifts in indices of striatal dopamine concentrations were different for the aforementioned amphetamine (Laruelle et al. 1995) and the present study. Similar percent changes in $\mathrm{D}_{2}$ receptor availability as measured by different methods ([123I]IBZM binding and $\left[{ }^{11} \mathrm{C}\right]$ raclopride $\mathrm{BP}$ ) may not necessarily reflect similar changes in extracellular dopamine concentrations. Second, the present correlation between depersonlisation and decrease in raclopride BP in the ventral striatum must be interpreted cautiously, since this decrease was only at a statistical trend level. Finally, the sample size of the present study was rather small. Further research with larger sample sizes will have to focus on using identical methodologies to study the effects of different serotonergic and dopaminergic drugs on striatal dopamine transmission and its relationship to various aspects of psychotic symptoms. Also, the involvment of extrastriatal dopamine transmission in psychotic states warrants further study using PET ligands specific to $D_{1} / D_{3}$ receptors.

The mechanisms by which psilocybin increases striatal dopamine release are unclear at this time. Given its lack of $\mathrm{D}_{2}$-dopamine receptor affinity and its strong agonist activity at $5-\mathrm{HT}_{2}$ and $5-\mathrm{HT}_{1}$ receptors, the present result strongly suggest that psilocybin may increase dopamine release through 5-HT receptor activation. This mechanism is consistent with recent studies demonstrating increased striatal dopamine levels after acute administration of the 5-HT releaser and uptake inhibitor fenfluramine (Smith et al. 1997) and chronic administration of the 5-HT uptake inhibitor citalopram (Tiihonen et al. 1996) in normal subjects as assessed by PET and $\left[{ }^{11} \mathrm{C}\right]$ raclopride. In animal studies, local application of 5-HT or 5-HT agonists by means of microdialysis was also reported to increase extracellular DA in the striatum (Benloucif and Galloway 1991; Benloucif et al. 1993; Bonhomme et al. 1995) and nucleus accumbens
(Guan and McBride 1989; Parson and Justice 1993; Boulenguez et al. 1996). However, there is a minority of studies reporting an inhibitory influence of serotonergic stimulation on striatal dopamine concentration (Dewey et al. 1995; Kapur and Remington 1996).

Whether psilocybin increases striatal dopamine release through $5-\mathrm{HT}_{2}$ receptor stimulation alone or in combination with $5-\mathrm{HT}_{1}$ receptors cannot be inferred from the present data. Moreover, the interpretation of the present data is complicated by the fact that $5-\mathrm{HT}_{2}$ receptor antagonism, but not $5-\mathrm{HT}_{2}$ receptor stimulation, is generally thought to enhance striatal dopamine release (Kapur and Remington 1996). For example, altanserin, a $5-\mathrm{HT}_{2}$ antagonist, has been shown to increase striatal dopamine release in baboons and rats (Dewey et al. 1995). However, there is substantial evidence from recent animal studies indicating that under certain conditions stimulation of $5-\mathrm{HT}_{2}$ receptors can facilitate striatal dopamine release (West and Galloway 1996). For example, it has been demonstrated that the potent 5-HT releasing agent MDMA increases impulsemediated striatal dopamine release and that this effect can be blocked by the highly selective $5-\mathrm{HT}_{2 \mathrm{~A}}$ antagonist MDL100,907 (Schmidt et al. 1992, 1993). The blocking effects of 5- $\mathrm{HT}_{2}$ antagonists on the MDMA-mediated dopamine release were most evident when the dopaminergic system was activated (Schmidt et al. 1993; Gudelsky and Nash 1996). Thus it has been suggested that these findings indicate a permissive role for $5-\mathrm{HT}_{2 \mathrm{~A}}$ receptors in the activation of the dopamine system, which may occur during states of high serotonergic activity or elevated dopamine efflux. Since psilocybin also acts upon 5- $\mathrm{HT}_{1 \mathrm{~A}}$ receptors (Buckholtz et al. 1990; McKenna et al. 1990) and stimulation of 5- $\mathrm{HT}_{1 \mathrm{~A}}$ autoreceptors is expected to enhance the dopaminergic tone (Neal-Beeliveau et al. 1993), one might speculate that psilocybin increases striatal dopamine release through a concomitant stimulation of both $5-\mathrm{HT}_{1 \mathrm{~A}}$ and $5-\mathrm{HT}_{2 \mathrm{~A}}$ receptors. This hypothesis is supported by the finding that $5-\mathrm{HT}_{1 \mathrm{~A}}$ agonists can facilitate dopamine release in the striatum and nucleus accumbens (Benloucif and Galloway 1991), while 5- $\mathrm{HT}_{1 \mathrm{~A}}$ antagonist have been reported to inhibit dopamine release in these brain regions (Parson and Justice 1993; Boulenguez et al. 1996; Nomikos et al. 1996). Furthermore, recent studies in rats demonstrated that the changes in locomotor activity produced by the $5-\mathrm{HT}_{1 \mathrm{~A}}$ agonist 8 -OH-DPAT (Hillegaart et al. 1995) or the classic indolehallucinogen LSD were attenuated by pretreatment with the selective 5- $\mathrm{HT}_{1 \mathrm{~A}}$ antagonist WAY-100,635 (Sipes and Geyer 1995; Krebs-Thomson and Geyer 1996). It is to be noted, however, that $5-\mathrm{HT}_{2}$ receptors have also been located on GABAergic interneurons, thus some of the effects of psilocybin on the dopamine system may be mediated, indirectly, through its modulation of the GABA system (Marek and Aghajanian 1994; Yamamoto et al. 1995). 
Certainly, such speculation needs substantial corroborative evidence and carefully designed mechanistic studies. Nevertheless, the present findings suggest that stimulation of $5-\mathrm{HT}$, presumably $5-\mathrm{HT}_{2}$ and $5-\mathrm{HT}_{1}$ receptors, can lead to an increase in striatal dopamine efflux which may contribute to the psychotomimetic effects of psilocybin. Of particular interest to the present study are indications that abnormalities in the number of 5- $\mathrm{HT}_{1 \mathrm{~A}}$ and $5-\mathrm{HT}_{2 \mathrm{~A}}$ receptors have been found in the frontal cortex, nucleus accumbens, striatum, and hippocampi of schizophrenic patients (Mita et al. 1986; Arora and Meltzer 1991; Joyce et al. 1993; Laruelle et al. 1993; Gurevich and Joyce 1997). Thus, the present data also support further evaluation of the 5-HT system in the pathophysiology of schizophrenia (Meltzer 1991).

\section{ACKNOWLEDGMENTS}

This study was financially supported in part by the Swiss National Research Foundation (32-40900.94) Switzerland. The authors especially thank Prof. M. Geyer, UCSD, Dr. D. Umbricht and A. Gamma (PUK) for critical comments on the manuscript.

\section{REFERENCES}

Aghajanian GK (1994): LSD and phenethylamine hallucinogens: common sites of neuronal action. In Pletscher A, Ladewig D (eds), 50 Years of LSD. Current Status and Perspectives of Hallucinogens. New York, The Parthenon Publishing Group, pp 27-41

Andreasen NC, Rezai K, Alliger R, Swayze VW, Flaum M, Kirchner P, Cohen G, O'Leary DS (1992): Hypofrontality in neuroleptic-naive patients and in patients with chronic schizophrenia. Arch Gen Psychiatry 49:943-958

Arora RC, Meltzer HY (1991): Serotonin 2 (5-HT2) receptor binding in the frontal cortex of schizophrenic patients. J Neural Transm 85:19-29

Benloucif S, Keegan MJ, Galloway MP (1993): Serotoninfacilitated dopamine release in vivo : Pharmacological characterization. J Pharmacol Exp Ther 265:373-377

Benloucif S, Galloway MP (1991): Facilitation of dopamine release in vivo by serotonin agonists: studies with microdialysis. Eur J Pharmacol 200:1-8

Blandina P, Goldfarb J, Green JP (1988): Activation of a 5-HT3 receptor releases dopamine from rat striatal slice. Eur J Pharmacol 155:349-350

Bonhomme N, De Deurwaerdere P, Le Moal M, Spampinato U (1995): Evidence for 5-HT4 receptor subtype involvement in the enhancement of striatal dopamine release induced by serotonin: A microdialysis study in the halothane-anesthetized rat. Neuropharmacology 34:269279

Boulenguez P, Rawlins JNP, Chauveau J, Joseph MH, Mitchell SN, Gray JA (1996): Modulation of dopamine release in the nuccleus accumbens by $5-\mathrm{HT} 1 \mathrm{~B}$ agonists-involve- ment of the hippocampo-accumbens pathway. Neuropharmacology 35:1521-1529

Bowers MB, Freedman DX (1966): "Psychedelic" experiences in acute psychoses. Arch Gen Psychiatry 15:240-248

Breier A, Adler CM, Weisenfeld N, Su TP, Elman I, Picken L, Malhotra AK, Pickar D (1998): Effects of NMDA antagonism on striatal dopamine release in healthy subjects application of a novel PET approach. Synapse 29:142147

Buchsbaum MS, Haier RJ, Potkin SG, Nuechterlein K, Bracha HS, Katz M, Lohr J, Lottenberg S, Jerabek PA, Trenary M, Tafalla R, Reynolds C, Bunney WE (1992): Frontostriatal disorder of cerebral metabolism in nevermedicated schizophrenics. Arch Gen Psychiatry 49:935942

Buckholtz NS, Zhou DF, Freedman DX, Potter WZ (1990): Lysergic acid diethylamide (LSD) administration selectively downregulates serotonin2 receptors in rat brain. Neuropsychopharmacology 3:137-148

Catafau AM, Parellada E, Lomena FJ, Bernardo M, Pavia J, Ros D, Setoain J, Gonzalez-Monclus E (1994): Prefrontal and temporal blood flow in schizophrenia: resting and activation technetium-99m-hmpao spect patterns in young neuroleptic-naive patients with acute disease. J Nucl Med 35:935-941

Chapman J (1966): The early symptoms of schizophrenia. Br J Psychiatry 112:225-251

Cleghorn JM, Garnett ES, Nahmias C, Firnau G, Brown GM, Kaplan R, Szechtman H, Szechtman B (1989): Increased frontal and reduced parietal glucose metabolism in acute untreated schizophrenia. Psychiatry Res 28:119 133

Creese I, Burt DR, Snyder SH (1975): The dopamine receptor: differential binding of d-LSD and related agents to agonist and antagonist states. Life Sciences 17:17151720

de Belleroche JS, Bradford HF (1980): Presynaptic control of the synthesis and release of dopamine from striatal synaptosomes: A coparison between the effects of 5-hydroxytryptamine, acetylcholine, and glutamate. J Neurochem 35:1227-1234

de Belleroche JS, Gardiner IM (1982): Contrasting effects of 5-hydroxytryptamine on the release of dopamine and acetylcholine in the nucleus accumbens of rat. J Neural Transm 55:227-242

De Deurwaerdere P, L'hirondel M, Bonhomme N, Lucas G, Cheramy AX, Spampinato U (1997): Serotonin stimulation of 5-HT4 receptors indirectly enhances in vivo dopamine release in the rat striatum. J Neurochem 68:195-203

Dewey SL, Smith GS, Logan J, Brodie JD, Fowler JS, Wolf AP (1993): Striatal binding of the PET ligand 11C-raclopride is altered by drugs that modify synaptic dopamine levels. Synapse 13:350-356

Dewey SL, Smith GS, Logan J, Alexoff D, Ding YS, King P, Pappas N, Brodie JD, Ashby CR, Jr (1995): Serotonergic modulation of striatal dopamine measured with positron emission tomography (PET) and in vivo microdialysis. J Neurosci 15:821-829

Dittrich A (1994): Psychological aspects of altered states of consciousness of the LSD type: measurements of their 
basic dimensions and prediction of individual differences. In Pletscher A, Ladewig D (eds), 50 Years of LSD. Current Status and Perspectives of Hallucinogens. New York, Parthenon Publishing, pp 101-118

Dittrich A (1996): Ätiologie-unabhängige Strukturen veränderter Wachbewusstseinszustände. Stuttgart, VWBVerlag für Wissenschaft und Bildung

Ebmeier KP, Blackwood DHR, Murray C, Souza V, Walker M, Doughall N, Moffoot APR, O'Carroll RE, Goodwin GM (1993): Single-photon emission computed tomography with 99mTc-Exametazime in unmedicated schizophrenic patients. Biol Psychiatry 33:487-495

Ebmeier KP, Lawrie SM, Blackwood DH, Johnstone EC, Goodwin GM (1995): Hypofrontality revisited: a high resolution single photon emission computed tomography study in schizophrenia. J Neurol Neurosurg Psychiat 58:452-456

Ennis C, Kemp JD, Cox B (1981): Characterisation of inhibitory 5-hydroxytryptamine receptors that modulate dopamine release in the stritatum. J Neurochem 36: 1515-1520

Fahrenberg J, Hampel R, Selg H (1984): Das Freiburger Persönlichkeitsinventar FPI. Göttingen, Hogrefe

Fischman LG (1983): Dreams, hallucinogenic drug states, and schizophrenia: A psychological and biological comparison. Schizophrenia Bull 9:73-94

Freedman B, Chapman LJ (1973): Early subjective experiences in schizophrenic episodes. J Abnorm Psychol 82:46-54

Gouzoulis E, Hermle L, Sass H (1994): Psychedelische Erlebnisse zu Beginn produktiver Episoden endogener Psychosen. Nervenarzt 65:198-201

Gouzoulis-Mayfrank E, Hermle L, Thelen B, Sass H (1998): History, rationale and potential of human experimental hallucinogen drug research in psychiatry. Pharmacopsychiat 31:63-68

Guan XM, McBride WJ (1989): Serotonin microinfusion into the ventral tegmental area increases accumbens dopamine release. Brain Res Bull 23:541-547

Gudelsky GA, Nash JF (1996): Carrier-mediated release of serotonin by 3,4-methylenedioxymethamphetamine: Implications for serotonin-dopamine interactions. J Neurochem 66:243-249

Gurevich EV, Joyce JN (1997): Alterations in the cortical serotonergic system in schizophrenia: A postmortem study. Biol Psychiatry 42:529-545

Hasler F, Bourquin D, Brenneisen R, Bär T, Vollenweider FX (1997): Determination of psilocin and 4-hydroxyindole3-acetic acid in plasma by HPLC-ECD and pharmacokinetic profiles of oral and intravenous psilocybin in man. Pharm Acta Helv 72:175-184

Heimann H (1986): Models of experience and behavior in psychotic disorders. Pharmacopsychiatry 19:128-133

Hillegaart V, Estival A, Ahlenius S (1995): Evidence for specific involvement of 5-HT1 and 5-HT2/AC receptors in the expression of patterns of spontaneous motor activity in the rat. Soc Neurosci Abstracts 1:1366

Joyce JN (1993): The dopamine hypothesis of schizophrenia: limbic interactions with serotonin and norepinephrine. Psychopharmacology 112:S16-34
Joyce JN, Shane A, Lexow N, Winokur A, Casanova M, Kleinmann JE (1993): Serotonin uptake sites and serotonin receptors are altered in the limbic system of schizophrenics. Neuropsychopharmacology 8:315-336

Kapur S, Remington G (1996): Serotonin-dopamine interaction and its relevance to schizophrenia. Am J Psychiatry 153:466-476

Krebs-Thomson K, Geyer MA (1996): The role of 5-HT1A receptors in the locomotor-suppressant effects of LSD:way-100635 studies of 8-OH-DPAT, DOI and LSD. Behav Pharmacol 6:551-559

Lammertsma AA, Hume SP (1996): Simplified reference tissue model for PET receptor studies. Neuroimage 4:153158

Laruelle M, Abi-Dargham A, Casanova F, Toti R, Weinberger DR, Kleinman JE (1993): Selective abnormalities of prefrontal serotonergic receptors in schizophrenia. Arch Gen Psychiatry 50:810-818

Laruelle M, Abi-Dargham A, van Dyck $\mathrm{CH}$, Rosenblatt W, Zea-Ponce Y, Zoghbi SS, Baldwin RM, Charney DS, Hoffer PB, Kung HF, Innis RB (1995): SPECT imaging of striatal dopamine release after amphetamine challenge. J Nucl Med 36:1182-1190

Laruelle M, Abi-Dargham A, van Dyck CH, Gil R, D'Souza $\mathrm{CD}$, Erdos J, McCance E, Rosenblatt W, Fingado C, Zoghbi SS, Baldwin RM, Seibyl JP, Krystal JH, Charney DS, Innis RB (1996): Single photon emission computerized tomography imaging of amphetamine-induced dopamine release in drug-free schizophrenic subjects. Proc Natl Acad Sci U S A 93:9235-9240

Liddle PF, Friston KJ, Frith CD, Hirsch SR, Jones T, Frackowiak RS (1992): Patterns of cerebral blood flow in schizophrenia. Br J Psychiatry 160:179-186

Marek GJ, Aghajanian GK (1994): Excitation of interneurons in piriform cortex by 5-hydroxytryptamine: blockade by MDL 100,907, a highly selective 5-HT2A receptor antagonist. Eur J Pharmacol 259:137-141

McCabe MS, Fowler RC, Cadoret RJ, Winokur G (1972): Symptom differences in schizophrenia with good and poor progosis. Am J Psychiatry 128:1239-1243

McKenna DJ, Nazarali AJ, Hoffman AJ, Nichols DE, Mathis CA, Saavedra JM (1989): Common receptors for hallucinogens in rat brain: a comparative autoradiographic study using (125 I) LSD and (125 I) DOI, a new psychotomimetic radioligand. Brain Res 476:45-56

McKenna DJ, Repke DB, Peroutka SJ (1990): Differential interactions of indolealkylamines with 5-hydroxytryptamine receptor subtypes. Neuropharmacology 29:193198

Meltzer HY (1991): The mechanism of action of novel antipsychotic drugs. Schizophrenia Bull 17:263-287.

Mita T, Hananda S, Nishino N, Kuno T, Nakai H, Yamdori T, Mizoi Y, Tanaka C (1986): Decreased serotonin S2 and increased dopamine D2 receptors in chronic schizophrenics. Biol Psychiatry 21:1407-1414

Neal-Beeliveau B, Joyce I, Lucki I (1993): Serotonergic involvement in haloperidol induced catalepsy. J Pharmacol Exp Ther 265:207-217

Nomikos GG, Arborelius L, Hook BB, Hachsell U, Svensson TH (1996): The 5-HT1A receptor antagonist (S)-UH-301 
decreases dopamine release in the rat nuccleus accumbens and striatum. J Neural Transm 103:541-554

Nordström A-L, Farde L, Pauli S, Litton J-E, Halldin C (1992): PET analysis of central (11C) raclopride binding in healthy young adults and schizophrenic patients-reliability and age effects. Human Psychopharmacology 7:157-165

Padich RA, McCloskey TC, Kehne JH (1996): 5-HT modulation of auditory and visual sensorimotor gating:II. Effects of the 5-HT2A antagonist MDL 100,907 on disruption of sound and light prepulse inhibition produced by 5 -HT agonists in Wistar rats. Psychopharmacology 124:107-116

Palacios JM, Wäber C, Mengold G, Pompeiano M (1991): Molecular neuroanatomy of 5-HT receptors. In Fozard J, Saxena P (eds), Serotonin: Molecular Biology, Receptors and Functional Effects. Basel, Birkhäuser Verlag, pp 5-19

Palfreyman MG, Schmidt CJ, Sorensen SM, Dudley MW, Kehne JH, Moser P, Gittos MW, Carr AA (1993): Electrophysiological, biochemical and behavioral evidence for 5-HT2 and 5-HT3 mediated control of dopaminergic function. Psychopharmacology 112:S60-S77

Parellada E, Catafau AM, Bernardo M, Lomeña F, GonzálezMonclús E, Setoain J (1994): Prefrontal dysfunction in young acute neuroleptic-naive schizophrenic patients: a resting and activation SPECT study. Psychiatry Research: Neuroimaging 55:131-139

Parson LH, Justice JB (1993): Perfusate serotonin increases extracellular dopamine release in the nucleus accumbens as mesuered by in vivo microdialysis. Brain Res 602:195-199

Pierce PA, Peroutka SJ (1989): Hallucinogenic drug interactions with neurotransmitter receptor binding sites in human cortex. Psychopharmacology 97:118-122

Rümmele W, Gnirss F (1961): Untersuchungen mit Psilocybin, einer psychotropen Substanz aus Psilocybe Mexicana. Schweiz Arch Neurol Psychiat 87:365-385

Sabri O, Erkwoh R, Schreckenberger M, Owega A, Sass H, Buell U (1997): Correlation of positive symptoms exclusively to hyperperfusion or hypoperfusion of cerebral cortex in never-treated schizophrenics. Lancet 349: 1735-1739

Schmidt CJ, Fadayel GM, Sullivan CK, Taylor VL (1992): 5-HT2 receptors exert a state-dependent regulation of dopaminergic function: studies with MDL 100,907 and the amphetamine analogue, 3,4-methylenedioxymethamphetamine. Eur J Pharmacol 223:65-74

Schmidt CJ, Kehne JH, Carr AA, Fadayel GM, Humphreys TM, Kettler HJ, McCloskey TC, Padich RA, Taylor VL, Sorensen SM (1993): Contribution of serotonin neurotoxins to understanding psychiatric disorders: The role of 5-HT2 receptors in schizophrenia and antipsychotic activity. Int Clin Psychopharmacol 8(Suppl 2):25-32

Schmidt CJ, Sullivan CK, Fadayel GM (1994): Blockade of striatal 5-hydroxytryptamine2 receptors reduces the increase in extracellular concentrations of dopamine produced by the amphetamine analogue 3,4-methylenedioxymethamphetamine. J Neurochem 62:1382-1389
Siegel BVJ, Buchsbaum MS, Bunney WEJ, Gottschalk LA, Haier RJ, Lohr JB, Lottenberg S, Najafi A, Nuechterlein KH, Potkin SG, Wu JC (1993): Cortical-striatal-thalamic circuits and brain glucose metabolic activity in 70 unmedicated male schizophrenic patients. Am J Psychiatry 150:1325-1336

Sipes TA, Geyer MA (1994): Multiple serotonin receptor subtypes modulate prepulse inhibition of the startle response in rats. Neuropharmacology 33:441-448

Sipes TA, Geyer MA (1995): 8-OH-DPAT disruption of prepulse inhibition in rats: reversal with $(+)$ WAY 100,135 and localization of site of action. Psychopharmacology 117:41-48

Smith GS, Dewey SL, Brodie JD, Logan J, Vitkun SA, Simkowitz P, Schloesser R, Alexoff DA, Hurley A, Cooper T, Volkow ND (1997): Serotonergic modulation of dopamine measured with [11C] raclopride and PET in normal human subjects. Am J Psychiatry 154:490-496

Spitzer M, Thimm M, Hermle L, Holzmann P, Kovar A, Heimann H, Gouzoulis E, Kischka U, Schneider F (1996): Increased activation of indirect semantic associations under psilocybin. Biol Psychiatry 39:1055-1057

Tiihonen J, Kuoppamaki M, Nagren K, Bergman J, Eronen E, Syvalahti EX, Hietala J (1996): Serotonergic modulation of striatal D2 dopamine receptor binding in humans measured with positron emission tomography. Psychopharmacology 126:277-280

Volkow ND, Fowler JS, Wang GJ, Dewey SL, Schlyer D, MacGregor RL, Logan J, Alexoff D, Shea C, Hitzemann R, Angrist B, Wolf (1993): Reproducibility of repeated measures of carbon-11-raclopride binding in the human brain. J Nucl Med 34:609-613

Vollenweider FX, Vollenweider-Scherpenhuyzen MFI, Bäbler A, Vogel H, Hell D (1998): Psilocybin induces schizophrenia-like psychosis in humans via a serotonin-2 agonist action. NeuroReport 9:3897-3902

Vollenweider FX, Leenders KL, Scharfetter C, Maguire P, Stadelmann O, Angst J (1997): Positron emission tomography and fluorodeoxyglucose studies of metabolic hyperfrontality and psychopathology in the psilocybin model of psychosis. Neuropsychopharmacology 16: 357-372

West AR, Galloway MP (1996): Regulation of serotonin-facilitated dopamine release in vivo: the role of protein kinase A activating transduction mechanisms. Synapse 23:20-27

Westfall TC, Tittermary V (1982): Inhibition of the electrically induced release of $[3 \mathrm{H}]$ dopamine by serotonin from superfused rat striatal slices. Neurosci Lett 28:205-209

Yamamoto BK, Nash JF, Gudelsky GA (1995): Modulation of methylenedioxymethamphetamine-induced striatal dopamine release by the interaction between serotonin and gamma-aminobutyric acid in the substantia nigra. J Pharmacol Exp Ther 273:1063-1070

Zazpe A, Artaiz I, Del Rio J (1994): Role of 5-HT3 receptors in basal and $\mathrm{K}(+)$-evoked dopamine release from rat olfactory tubercle and striatal slices. Br J Pharmacol 113:968-972 